\title{
Working with Nonprofit Organizations in Community Settings: Governance, Board Manual
}

Elizabeth B. Bolton and Lynda M. Spence

\section{Importance of \\ Board Manual or Handbook}

The board is the policy-making arm of the nonprofit organization. The work it does and the decisions it makes affect the entire organization, its client groups, and, to a great extent, the community in which it serves. Members of the board are volunteers. Even though they serve without compensation, their roles and responsibilities must be clearly defined. As in every for-profit and nonprofit organization, board members do not hold office in perpetuity. Guidance for incoming as well as holdover members should be established in a Board Manual or Board Handbook-use the manual to orient and educate members and officers on all aspects of the organization and board functions. A board manual also informs the recruitment process for prospective board members and serves to engage potential funders. In this manner, a well-planned board manual significantly contributes to the sustainability of the organization.

The elements in a board's guide or manual are described below and may be adapted to meet the needs of the respective organization. Components of this guide include, but are not limited to the organization's history, mission, and offices.

\section{Essential Elements of the Board Manual}

\section{The board as an organization}

A description can be an organizational chart or simply a listing of the offices, their functions, how they are elected or appointed, the length of service and qualifications for each position. A more detailed description may include the specific duties associated with each office.

1. This publication is FCS9249, one of a series of the Department of Family, Youth and Community Sciences, Florida Cooperative Extension Service, Institute of Food and Agricultural Sciences, University of Florida. First published: June 2009. Please visit the EDIS Web site at http://edis.ifas.ufl.edu. Reviewed June 2012.

2. Elizabeth B. Bolton, Ph.D., professor of Community Development, Department of Family, Youth and Community Sciences; Florida Cooperative Extension Service; Institute of Food and Agricultural Sciences; University of Florida; Gainesville, Florida 32611 - 0310; and, Lynda M. Spence, MS, extension agent; Marion County Cooperative Extension; Ocala, FL 33470 - 3615. 


\section{Current board officers}

A list of the officers and committee chairs is an inspiration to others to serve in these offices. A short bio of members may be included if desired. List the members of the committees along with the chairs. It is also helpful to have a separate listing of past officers and the years they served.

\section{History of the organization}

This chapter should be carefully written with attention to significant dates, facts and individuals. When was it founded and for what purpose? Who are/were the founding members and what did they do to launch the organization? Has the mission changed over the years, and, if so, why and how? Past members and officers who are currently inactive, yet are still vested, may be asked to contribute to this section. Their work can be circulated to others for additions and editing. Significant accomplishments or events may also be included in this section. While interesting and informative, care should be taken to not overdevelop this section; rather, just succinctly present the essentials. A rich history may be documented in a separate, yet equally relevant publication as an archival treasure.

\section{Strategic framework with mission, vision, and objectives}

This section will help new and prospective board members understand the organization's scope, target group, sources of funding, and timeline for programming. Further, it helps to explain and demonstrate the relationship between programming and mission. The current operating plan, with objectives and the cost of attaining those objectives should be included in this section. Due to changes in funding and outreach programming, it is essential to keep this section current. Although the sustainable organization adapts as circumstances change, its core mission does not. Utmost care must be taken to assure all actions and activities remain consistent with the mission of the organization even if that mission evolves. This portion of your board manual should lay the groundwork for this assurance.

\section{Board policies}

The policies chapter includes information about expense reporting and reimbursement, travel to conferences and meetings, insurance, compensation guidelines for services provided by outside sources, such as a CPA firm, attendance at board meetings, etc. As the organization matures, the policy section will mature with it. Some policies may be eliminated and some will need amending. When policies are changed by board mandate, the date the change was passed should be recorded.

\section{Minutes for the past year's board meetings}

Minutes are typically a page or two and document key items on the agenda, as well as any new business presented for the board's consideration. Keep minutes short and to the point, but pay attention to accuracy. Avoid detailed narratives and descriptions unless deemed essential to the agenda item. The minutes have significance because they are a record of board member attendance and contributions, as well as the meeting's agenda and the business that was transacted.

\section{Financial statements}

In the age of transparency and accountability, it is important to include the annual financial statements as well as the audits. The treasurer prepares these, and although they might not all have the same date, it is very important that they be included. Typically, the financial statements section should include the balance sheet, a statement of revenues and expenses, and other annual records such as the income report to the IRS and Form 990. An external auditor's report may also be included if applicable. 


\section{Legal documents}

A copy of the bylaws is an absolute must for the board members' manual. The bylaws are the guiding legal document for the organization and these are amended when needed; without a working copy of the bylaws, board members may be operating without sufficient knowledge of the legal framework. There may be other legal documents that the board considers important to include, which can be easily accommodated.

\section{Staff}

The names of all staff members, their job titles, and an overview of each employee's duties should be shown. Include contact information and pictures if desired.

\section{Other}

You may also wish to include an annual calendar of organizational activities and board meeting dates, along with Web site information, promotional materials, and other items of interest and importance in this section. 